\title{
KARAKTERISTIK PENGGUNA TUMBUHAN OBAT DI HUTAN LINDUNG JOMPI KABUPATEN MUNA SULAWESI TENGGARA
}

\section{(The User Characteristics of Medicinal Plants by the Community in Jompi Forest, Muna Regency, Southeast Sulawesi)}

\author{
Ernikawati $^{1}$, Ervizal A.M. Zuhud ${ }^{2}$, dan Yanto Santosa ${ }^{3}$ \\ ${ }^{1}$ Staf Pengajar Kehutaann Universitas Gorontalo, Jln. A.A.Wahab NO.247 Kel.Kayu \\ Bulan Kec.Limboto Kabupaten Gorontalo \\ ${ }^{2.3)}$ Departemen Konservasi Sumberdaya Hutan dan Ekowisata Fakultas Kehutanan IPB, \\ Jl. Lingkar Akademik Kampus IPB Dramaga Bogor \\ Email : ernikawatimikha@gmail.com
}

\begin{abstract}
The user characteristics of medicinal plants by the protected forest communities in Jompi is known as a tropical medicine which can cure various diseases. The purpose of this study is to examine the characteristics of medicinal plant users based on their age, education, income, number of family dependents, local knowledge and livelihoods. The research method used interviews conducted with 30 respondents. The results showed that the characteristics of respondents based on the productive age of middle-aged adults amounted to 14 people or $46.67 \%$, education (primary school graduates) amounted to 17 people or $43.33 \%$, income of 17 people or 56.67 , family dependents amounted to 8 people or $(26.67 \%)$, local knowledge, that is, the local community numbered 20 people or $(66.67 \%)$ and based on livelihoods, namely farmers, amounting to 15 people or $50 \%$. The main conclusion of this study is that the characteristics of respondents using medicinal plants very closely related to using medicinal plants.
\end{abstract}

\section{Keywords: Protected Forest, Respondent Characteristics, Medicinal Plants}

\begin{abstract}
Abstrak
Karakteristik pengguna tumbuhan obat oleh masyarakat hutan lindung Jompi dikenal sebagai bahan obat-obatan tropis yang dapat menyembuhkan barbagai macam penyakit. Tujuan penelitian ini yaitu untuk mengkaji karakteristik pengguna tumbuhan obat berdasarkan tingkat umur, pendidikan, pendapatan, jumlah tanggungan keluarga, pengetahuan lokal dan mata pencaharian. Metode penelitian yang digunakan yaitu wawancara terhadap 30 responden. Hasil penelitian menunjukan bahwa karakteristik responden berdasarkan umur produktif dewasa madya berjumlah 14 orang atau 46.67\%, pendidikan (tamat SD) berjumlah 17 orang atau $43.33 \%$, pendapatan sebanyak 17 orang atau 56.67, jumlah tanggungan keluarga berjumlah 8 orang atau (26.67\%), pengetahuan lokal yaitu masyarakat lokal berjumlah 20 orang atau (66.67\%) serta berdasarkan mata pencaharian yaitu petani berjumlah 15 orang atau $50 \%$. Simpulan utama dari penelitian ini bahwa karakteristik responden pengguna tumbuhan obat sangat berkaitan erat dengan memanfaatkan tumbuhan obat.
\end{abstract}

Kata kunci: Hutan Lindung, Karakteristik Responden, Tumbuhan Obat 


\section{PENDAHULUAN}

Penggunaan tumbuhan obat sebagai bahan obat sudah sejak lama dilakukan oleh masyarakat Desa Wali (Suku Muna). Dengan keanekaragaman etnis yang ada maka pemanfaatan sebagai obat juga semakin beraneka ragam (Zuhud 2011). Masyarakat Suku Muna sudah mengenal obat dari zaman dahulu, khususnya obat yang berasal dari tumbuh-tumbuhan seiring dengan meningkatnya jenis penyakit semakin meningkat dan pengetahuan tentang penggunaan tumbuhan obat sebagai sumber obat-obatan.

Dalam penggunaan dan pengembangan tanaman obat, juga dapat diperhatikan pelestarian dan perlindungannya. Namun demikian, tumbuhan obat sangat penting untuk diselamatkan serta dapat dioptimalkan pemanfaatannya. Penggunaan tumbuhan obat tradisional untuk pemeliharaan kesehatan dan gangguan penyakit hingga saat ini masih sangat dibutuhkan serta perlu untuk dikembangkan. Dimana dengan melonjaknya biaya pengobatan dan harga obat-obatan yang sangat mahal. Maka dapat dilihat bahwa adanya kenyataan tingkat kebutuhan masyarakat terhadap pengobatan semakin meningkat, sementara kehidupan sebagian masih banyak yang kemampuannya sangat terbatas. Olehnya itu, pengobatan dengan menggunakan bahan alam yang ekonomis merupakan solusi yang tepat untuk menanggulangi masalah tersebut (Arniputri et. al 2007).

Pengembangan obat alami patut mendapatkan perhatian yang lebih besar, bukan saja disebabkan potensi data karakteristik pengguna tumbuhan obat, pertama pengambilan data karakteristik pengembangannya yang terbuka namun, permintaan pasar akan bahan baku obat tradisional terus meningkat baik kebutuhan domestik maupun internasional. Hal ini tentunya juga akan berdampak positif bagi peningkatan pendapatan petani dan penerapapan tenaga kerja baik dalam usaha tani maupun dalam usaha pengolahannya. Obat tradisional merupakan aset yang perlu terus digali, diteliti, dikembangkan, dioptimalkan pemanfaatannya dan pengembangannya. Pengetahuan ini merupakan aset nasional, aset bangsa yang yang dapat dimanfaatkan dan dikembangkan serta diselamatkan karena sangat potensial untuk dikembangkan, dibudidayakan serta dilestarikan (Noorhidayah et.al 2017). Adapun penelitian ini fokus mengkaji karakteristik pengguna tumbuhan obat pohon yang meliputi tingkat umur, pendidikan, pendapatan, tanggungan keluarga, pengetahuan lokal serta mata pencaharian.

Tujuan penelitian ini adalah untuk mengkaji karakteristik pengguna tumbuhan obat di Hutan Lindung Jompi berdasarkan tingkat umur, pendidikan, pendapatan, jumlah tanggungan keluarga, pengetahuan lokal dan mata pencaharian. Peneltian ini diharapkan dapat menjadi sumber pengetahuan baru bagi masyarakat luas dan bisa dijadikan sebagai bahan rujukan penelitian selanjutnya yang berkaitan dengan karakteristik pengguna/pemanfaat tumbuhan obat yang ada di hutan Lindung Jompi.

\section{METODOLOGI PENELITIAN}

Penelitian ini dilaksanakan di Hutan Lindung Jompi, Kabupaten Muna Sulawesi Tenggara. Penelitian dilaksanakan Maret hingga Agustus 2016. Metode pengumpulan tumbuhan obat dilakukan dengan metode wawancara, kemudian pembagian kuisioner 
kepada masyarakat (responden) sebanyak 30 responden. Metode wawancara dilakukan dengan cara semi terstruktur dan pengamatan langsung terhadap kehidupan masyarakat desa Wali serta menggunakan kuisioner dengan pendalaman pertanyaan sesuai keperluan.

Pengumpulan data untuk melihat karakteristik responden tumbuhan obat berdasarkan tingkat umur, pendidikan, pendapatan, jumlah tanggungan keluarga, pengetahuan lokal dan mata pencaharian diperoleh dari hasil wawancara dan studi

\section{HASIL DAN PEMBAHASAN}

\section{Karakteristik Pengguna Tumbuhan Obat}

Umur literatur. Pemilihan responden dilakukan dengan menentukan orang yang dianggap paling banyak menggunakan tumbuhan sebagai obat, yakni responden berikutnya didasarkan atas informasi dari responden sebelumnya. Dilakukan dengan wawancara mendalam dengan menetapkan responden kunci (key person) Lovadi \& Meliki 2013). Analisis data yang digunakan adalah analisis deskriptif dan dikelompokan dengan cara tabulasi.

Berdasarkan hasil wawancara dilingkungan masyarakat bahwa umur/usia pemanfaatan tumbuhan obat di

Desa Wali berkisar antara 15->65 tahun. Pemanfaat tumbuhan obat dapat dikelompokan menjadi 4 kelompok umur, dapat dilihat pada Tabel 1 berikut:

Tabel 1 Karakteristik responden berdasarkan umur

\begin{tabular}{llrrr}
\hline NO & Karakteristik Umur & $\begin{array}{l}\text { Kelompok } \\
\text { (Umur) }\end{array}$ & Usia & \multicolumn{2}{c}{$\begin{array}{c}\text { Jumlah responden } \\
\text { Desa Wali }\end{array}$} \\
\cline { 4 - 5 } & & & Jumlah (org) & Presentasi (\%) \\
\hline 1 & Remaja & $15-19$ & 2 & 6.67 \\
2 & Desa Awal & $20-40$ & 11 & 33.33 \\
3 & Desa Madya & $41-65$ & 14 & 46.67 \\
4 & Desa lanjut/lansia & $>65$ & 3 & 13.33 \\
\hline
\end{tabular}

Berdasarkan kisaran umur/usia pada (Tabel 1) terlihat persentase pemanfaat tumbuhan obat tersebar di dominasi oleh masyarakat yang berusia 41-65 tahun yaitu sebesar 46.67\%. Dari data diatas maka diketahui bahwa, masyarakat umur produktif yang umumnya telah berusia dewasa madya hingga lanjut banyak menggunakan tumbuhan obat dibandingkan usia muda (Voeks 2007).
Menurut Puspitawati dan Herien (2010) membagi kategori umur dewasa manusia menjadi tiga, yaitu dewasa awal (20-40) tahun, dewasa madya (41-65) tahun dan dewasa lanjut/lansia (>65) tahun. Usia remaja dapat diperkirakan 15-19 tahun. Responden yang termasuk kedalam kategori dalam dewasa awal dan dewasa madya banyak memberikan informasi tentang tumbuhan obat. Usia muda lebih memilih menggunakan obat kimia 
dibanding obat tradisional karena kurangnya mendapatkan informasi mengenai tumbuhan obat alami kepada dewasa madya mengenai tumbuhan obat tradisionaal itu sendiri. Sebagian masyarakat berumur produktif telah lama tinggal dikawasan hutan Jompi dan telah banyak berinteraksi dengan kawasan hutan yang ada. Selain itu, mereka lebih mengetahui bagaimana cara memanfaatkan suatu spesies tumbuhan berhasiat obat yang telah digunakan dalam kehidupan seharihari secara turun-temurun. Namun demikian, umur responden terdiri remaja, dewasa dan lansia. Hal ini dikarenakan dalam kehidupan sehari-sehari mereka menggunakan dan memanfaatkan tumbuhan obat secara langsung. Responden dewasa lanjut/lansia sebenarnya memiliki pengetahuan akan tumbuhan obat yang tinggi. Akan tetapi, faktor daya ingat yang menurun (pikun) menyebabkan responden klasifikasi dewasa lanjut kurang dapat memberikan informasi.

\section{Lama Menempuh Pendidikan}

Hasil wawancara yang dilakukan menunjukan bahwa Pendidikan masyarakat pemanfaat tumbuhan obat di desa Wali yaitu mulai dari tingkat pendidikan rendah (Tamat SD) yaitu 43\% atau berjumlah 13 orang, Pendidikan Menengah (SMP/SMA) yaitu $23 \%$ atau berjumlah 7 orang sedangkan untuk Pendidikan Tinggi (Perguruan Tinggi) yaitu 33\% orang atau 10 orang. Perincian tingkat pendidikan pemanfaat tumbuhan obat selengkapnya disajikan pada (Tabel 2)

Tabel 2 Karakteristik responden berdasarkan Pendidikan

\begin{tabular}{llrr}
\hline NO & Karakteristik Pendidikan & \multicolumn{2}{c}{$\begin{array}{c}\text { Jumlah responden } \\
\text { Desa Wali }\end{array}$} \\
\cline { 3 - 4 } & & Jumlah (org) & Presentasi (\%) \\
\hline 1 & Pendidikan rendah (tamat SD) & 17 & 43.33 \\
2 & Pendidikan menengah (SMP/SMA) & 3 & 23.33 \\
3 & Pendidikan tinggi (Perguruan Tinggi) & 10 & 33.33 \\
\hline
\end{tabular}

Berdasarkan (Tabel 2) menunjukan bahwa masyarakat Desa Wali memiliki paling banyak pendidikan rendah (Tamat SD) hal ini disebabkan karena ketidakmampuan orang tua menyekolahkan kejenjang yang lebih tinggi. Terdapat keterkaitan antara pengetahuan yang dimiliki responden yang tamat SD dengan minimnya pengetahuan yang dimiliki mengenai pemanfaatan tumbuhan obat. Hal ini mencerminkan bahwa masih rendahnya tingkat pendidikan desa tersebut. Umumnya pengetahuan mereka peroleh dari pemanfaatan tumbuhan obat berasal dari orang tua atau turun temurun dari hasil tukar pikiran (Case et.al 2005).

Sebagian besar pemanfaat tumbuhan obat sekitar hutan lindung Jompi berlatar belakang pendidikan SD, yaitu sebesar $43.33 \%$ karena mengganggap bahwa menggunakan obat-obatan tradisional merupakan langkah yang paling efektif untuk mengobati suatu penyakit tertentu dibandingkan dengan berobat ke puskesmas/rumah sakit yang memerlukan biaya lebih besar. Masyarakat lebih memahami pengobatan suatu penyakit secara tradisional yang diperoleh secara turun temurun dibandingkan dengan pengobatan secara medis. Semakin tinggi 
Volume 2 Nomor 1 Juli 2020:11-19

pendidikan masyarakat, mereka cenderung akan memilih untuk borobat ke dokter/rumah sakit karena mereka lebih percaya akan pengobatan medis dalam penyembuhan suatu penyakit daripada meramu sendiri dari pada bahan-bahan yang sulit diperoleh dan sulit mengolahnya serta lebih lama dibandingkan dengan obat kimia. Oleh karena itu semakin tinggi pendidikan yang dimiliki maka semakin berkurang dalam menggunakan obat tradisional karena menurut pandangan mereka obat medis lebih cepat menyembuhkan penyakit dan secara medis sudah teruji secara klinis (Izin Departemen Kesehatan) dan dosisnya juga sesuai resep dokter, sementara obat tradisional secara medis belum teruji secara klinis.

\section{Pendapatan}

Berdasarkan hasil wawancara bahwa dari 30 responden desa Wali yang ada bahwa sebagian besar yaitu $57 \%$ atau berjumlah 17 orang termasuk dalam kategori pendapatan rendah. Pendapatan responden terdiri dari pendapatan rendah dan pendapatan tinggi dapat diliha pada (Tabel 3)

Tabel 3 responden berdasarkan pendapatan

\begin{tabular}{llrr}
\hline NO & Karakteristik Pendapatan & \multicolumn{2}{c}{$\begin{array}{c}\text { Jumlah responden } \\
\text { Desa Wali }\end{array}$} \\
\cline { 3 - 4 } & & Jumlah (org) & Presentasi (\%) \\
\hline 1 & Pendapatan rendah $(<\operatorname{Rp~500.000)~}$ & 17 & 56.67 \\
2 & Pendapatan tinggi $(\operatorname{Rp~1.500.000>Rp}$ & 13 & 43.33 \\
& 1. 175.000) & & \\
\hline
\end{tabular}

Komposisi tingkat penghasilan responden paling besar sebesar Rp. 1.500.000 - Rp 1 . 175.000, sebanyak 13 orang $43 \%$ dan 10 orang atau $33.33 \%$. Nugraha (2007) menyatakan bahwa partisipasi ditentukan oleh kemampuan dan kesanggupan untuk berpartisipasi dapat ditentukan oleh kemampuan, kemauan dan kesempatan. Hal ini sejalan dengan pernyataan Soedjono (2003) bahwa besar pendapatan akan berkorelasi positif dengan kemampuan dan kesanggupan untuk berpartisipasi dalam suatu kegiatan. Pendapatan rendah sangat berhubungan dengan penggunaan tumbuhan obat. Pendapatan rendah lebih memilih pengobatan tradisional/menggunakan tumbuhan obat ketika menderita sakit karena leratif lebih mudah dan cepat terjangkau serta diyakini dapat menyembuhkan berbagai jenis penyakit (Hidayat et.al 2011). Namun sebaliknya yang memiliki pendapatan tinggi pilihan pertama untuk mengatasi penyakitnya tentu akan memilih dokter atau tenaga medis untuk memeriksa dan memilihkan obat modern yang sesuai dengan keluhannya.

\section{Jumlah Tanggungan Keluarga}

Berdasarkan hasil wawancara yg diperoleh bahwa besarnya tanggungan keluarga sangat terkait dengan tingkat pendapatan seseorang. semakin besar jumlah tanggungan keluarga yang menyebabkan seseorang memerlukan tambahan penghasilan yang lebih tinggi untuk menutupi biaya kehidupannya. 
Tabel 4. Karakteristik responden berdasarkan jumlah tanggungan keluarga

\begin{tabular}{cccr}
\hline NO & Karakteristik Tanggungan keluarga & \multicolumn{2}{c}{$\begin{array}{c}\text { Jumlah responden } \\
\text { Desa Wali }\end{array}$} \\
\cline { 3 - 4 } & & Jumlah (org) & Presentasi (\%) \\
\hline 1 & $1-3$ & 5 & 16.67 \\
2 & $4-6$ & 4 & 13.33 \\
3 & $7-9$ & 6 & 20 \\
4 & $10-13$ & 8 & 26.67 \\
5 & $14-16$ & 7 & 23.33 \\
\hline
\end{tabular}

Hodi et.al (2010) menyatakan bahwa semakin besar tanggungan keluarga maka dibutuhkan tingkat aktifitas yang lebih tinggi dalam memenuhi kebutuhan hidup. Tanggungan keluarga dapat dibagi menjadi 5 yaitu tanggungan keluarga berjumlah 1-3 orang atau 16. 67\%, 4-6 tanggungan keluarga berjumlah 4 orang (13.33), 7-9 tanggungan keluarga (20\%), 10-13 tanggungan keluarga berjumlah 8 orang (26.67\%) serta 14-16 tanggungan keluarga berjumlah 7 orang (23.33\%). Berdasarkan (Tabel 4) diatas, maka hal ini menunjukan bahwa responden pengguna tumbuhan obat menyadari untuk tidak memiliki tanggungan keluarga yang banyak karena dapat menambah beban biaya hidup serta mengurangi pendapatan.

\section{Pengetahuan Lokal}

Pengetahuan lokal pengguna tumbuhan obat tertingi dimiliki oleh masyarakat desa Wali yaitu $66.67 \%$ atau sejumlah 20\% (Tabel 5). Masyarakat lokal dapat memberi informasi terhadap masyarakat pendatang dalam bentuk penyuluhan. Penyuluhan bagi masyarakat sangat diperlukan untuk memberikan informasi atau dapat meningkatkan pengetahuan mengenai potensi obat tradisonal. Penyuluhan tersebut diharapkan agar dapat memberikan pengetahuan yang baik kepada masyarakat pendatang sehingga dapat mengubah perilaku masyarakat yang tadinya tidak suka mengonsumsi obat tradisional menjadi tertarik untuk mengonsumsi obat tradisional. Hal ini sejalan dengan penelitian Yuniarti et.al 2012; Supriyadi et.al 2011 menyatakan bahwa ada hubungan antara pengetahuan dan penggunaan obat tradisonal.

Tabel 5 Karakteristik responden berdasarkan pengetahuan lokal

\begin{tabular}{clrc}
\hline NO & Karakteristik Pengetahuan lokal & \multicolumn{2}{c}{$\begin{array}{c}\text { Jumlah responden } \\
\text { Desa Wali }\end{array}$} \\
\cline { 3 - 4 } & & Jumlah (org) & Presentasi (\%) \\
\hline 1 & Masyarakat lokal & 20 & 66.67 \\
2 & Masyarakat Pendatang & 10 & 33.33 \\
\hline
\end{tabular}

Dari Tabel (5) menunjukan bahwa mayoritas masyarakat yang memanfaatkan tumbuhan obat adalah masyarakat asli (lokal) dari wilayah desa Wali (suku Muna), hal ini dikarenakan sejak lahir mereka telah tinggal di sekitar kawasan hutan lindung Jompi. Hubungan masyarakat lokal dengan menggunakan tumbuhan obat masih sangat tinggi dengan jumlah responden 20 atau $(66.67 \%)$. Bila dibandingkan dengan 
Volume 2 Nomor 1 Juli 2020:11-19

masyarakat pendatang dengan jumlah 10 orang atau $(33.33 \%)$. Namun, masyarakat pendatang layaknya hanya sebagai pendatang di kawasan tersebut dan mereka tidak bermukim menetap serta interaksi mereka terhadap kawasan hutan tidak begitu besar, sehingga mereka tidak banyak mengerti akan pemanfaatan suatu spesies tumbuhan obat di sekitar tempat tinggalnya.

\section{Mata Pencaharian}

Mata pencaharian petani merupakan mata pencaharian pokok. Petani khususnya bertani jagung merupakan faktor utama ketahanan pangan di Kabupaten Muna di desa Wali. Hal ini disebabkan karena kegiatan bertani merupakan kegiatan utama untuk memenuhi kebutuhan mereka dan sudah menjadi budaya yang sulit ditinggalkan. Masyarakat bermata pencaharian dukun bayi, dikarenakan desa tersebut memiliki keterampilan dibidang persalinan berprofesi sebagai dukun bayi (Leunufna 2016). Untuk masyarakat yang bermata pencaharian PNS dapat dikarenakan salah satu dari masyarakat tersebut memiliki pendidikan yang lebih tinggi dari masyarakat pada umumnya dan memiliki keahlian tersendiri untuk bekerja di kantor desa. Masyarakat Muna yang memanfaatkan tumbuhan obat memiliki pekerjaan terbanyak sebagai petani.

Tabel (6) Karakteristik responden berdasarkan Mata pencaharian

\begin{tabular}{llrr}
\hline NO & Karakteristik Mata pencaharian & \multicolumn{2}{c}{ Jumlah responden } \\
\cline { 3 - 4 } & & \multicolumn{2}{c}{ Desa Wali } \\
\hline 1 & Petani & 15 & 50 \\
2 & Dukun Bayi & 12 & 40 \\
3 & Pedagang & 2 & 6.67 \\
4 & PNS & \multicolumn{2}{c}{ Presentasi (\%) } \\
\hline
\end{tabular}

Hal ini sesuai dengan Rothers et.al (2011) yang menyatakan bahwa masyarakat di kecamatan Watopute di Desa Wali termasuk masyarakat yang agroholtikultura yaitu bermata pencaharian pada bidang pertanian. Hasil wawancara yang dilakukan di Desa Wali, diperoleh beberapa responden yang bermata pencaharian bertani, pedagang, dukun bayi serta PNS. Mata pencaharian petani lebih banyak dari pada mata pencaharian lainnya. Masyarakat pemanfaat tumbuhan obat di dominasi oleh responden yang bermata pencaharian sebagai petani $(50 \%)$, dukun bayi $(40 \%)$, pedagang $(6.67 \%)$ dan PNS $(3.33 \%)$. Hal ini dikarenakan memilih bekerja di ladang sekitar perkebunan yang lokasinya berbatasan dengan kawasan hutan Lindung Jompi, sehingga dalam kelestariannya mereka banyak mengetahui informasi spesies-spesies tumbuhan berkhasiat/bermanfaat untuk obat juga karena tempat tinggal mereka yang jauh dari perkotaan menyebabkan lebih bergantung pada pengobatan secara tradisional dibandingkan berobat ke dokter/rumah sakit tertentu. Masyarakat yang bermata pencaharian lain seperti pedagang $(6.67 \%)$ dan PNS (3.33\%) sedikit memanfaatkan tumbuhan obat, karena bekerja diperkotaan, sehingga lebih banyak menggunakan yang di jual ditoko, apotik serta warung terdekat. 


\section{KESIMPULAN}

Karakteristik responden berdasarkan tingkat umur, pendidikan, pendapatan, jumlah tanggungan keluarga, pengetahuan lokal dan mata pencaharian sangat berkaitan erat dalam memanfaatkan tumbuhan obat

\section{DAFTAR PUSTAKA}

Arniputri, Bandriati R, Sakya AT, Rahayu MUJI. 2007. Identifikasi Komponen Utama Minyak Atsiri Temukunci (Kaemferia pandurata Roxb.) pada Ketinggian Tempat yang Berbeda. Biodiversitas 8.(2):35-7.

Case RJ, Pauli GF, Soejarto DD. 2005. Factor in Maintaining Indeginous knowledge Among Ethnic Comunities of Manus Island. Economis Botany. 59(4):356-365.

Hidayat, Ana, Perwitasari DA. 2011. Persepsi Pengunjung Apotek Mengenai Penggunaan Obat Bahan Alam Sebagai Alternatif Pengobatan Di Kelurahan Muja Muju Kecamatan Umbulharjo kota yogyakarta. Kerjasama Fakultas Farmasi dan Fakultas Kesehatan Masyarakat Universitas Ahmad Dahlan. 119-128. Hodi F, Stephen, Steven J. O'day, David F. McDermott, Robert W. Weber, Jeffrey A. Sosman, John B. Haanen, Rene Gonzalez. 2010. Improved survival with ipilimumab in patients with metastatic melanoma. N Engl j Med. 363: 711723.

Leunufna S. 2016. Kriopreservasi untuk konservasi plasma nutfah tanaman: Peluang pemanfaatannya di Indonesia. J AgroBiogen. 3(2):80-88.

Lovadi I, Meliki RL. 2013. Etnobotani tumbuhan obat oleh suku dayak iban desa Tanjung Sari Kecamatan Ketungau Tengah Kabupaten Sintang. J Protobiont. 2(3): 24-3.

Noorhidayah N. 2017. Potensi dan keanekaragaman tumbuhan obat di hutan Kalimantan dan upaya konservasinya. J Analisis Kebijakan Kehutanan. 3(2):95-107.

Nugraha, Haddi K, Soedodo S, Anthony R. 2007. Hubungan Antara Persepsi Masyarakat tentang Ruang Terbuka Hijau dan Etika Lingkungan dengan Partisipasi Masyarakat dalam Pengembangan Kota yang Berwawasan Lingkungan. J pendidikan lingkungan hidup. 1(1).145.

Puspitawati, Herien. 2010. Pengaruh karakteristik sosial ekonomi keluarga terhadap pola asuh belajar siswa sekolah dasar dan menengah pertama. J Ilmu Keluarga dan Konsumen. 3(1): 46-55.

Rothers J, Wright AL, Stern DA, Halonen M, Camargo CA. 2011. Cord blood 25hydroxyvitamin D levels are associated with aeroallergen sensitization in children from Tucson, Arizona. J of Allergy and Clinical Immunology. 128(5):1093-1099.

Soedjono S. 2003. Aplikasi mutasi induksi dan variasi somaklonal dalam pemuliaan tanaman. J Litbang Pertanian. 22(2): 70-78.

Supriyadi, Eddy, Pudjo H. Widjajanto, Ignatius Purwanto, Jacqueline Cloos, Anjo JP Veerman, Sutaryo S. 2011. Incidence of childhood leukemia in Yogyakarta, Indonesia. Pediatric blood \& cancer. 57 (4):588-593.

Voeks RA. 2007. Are Woman Reservoir of Traditional Plant Knowledge? 


\section{Jurnal Penelitian Kehutanan Bonita}

Volume 2 Nomor 1 Juli 2020:11-19

Gender, Ethnobotany and

Globalization in Northeast Brazil.

Singapore . J of Tropical Geography. 28: 7-20.

Yuniari A, Kasmudjiastuti E. 2012. Spektroscopi FTIR dan sifat mekanik nanokomposit grafting HDPE dan nanoprecipitated calcium carbonate
(NPCC). Majalah Kulit, Karet, dan Plastik. 28(2):89-96.

Zuhud EAM. 2011. Potensi hutan Tropika Indonesia sebagai penyangga obat alam untuk kesehatan bangsa.ww.biology ast borneo.com/wpcontent/uploads/2011/ potensi hutan-sumber-obat.pdf[6 Januari 2015]. 